\title{
The Presence of Toxocara Eggs on Dog's Fur as Potential Zoonotic Risk in Animal-Assisted Interventions: A Systematic Review
}

\author{
Maria Paola Maurelli ${ }^{1, *}$, Antonio Santaniello ${ }^{2, *} \mathbb{1}$, Alessandro Fioretti ${ }^{2}$, Giuseppe Cringoli ${ }^{1}$, \\ Laura Rinaldi ${ }^{1}$ and Lucia Francesca Menna ${ }^{2}$ \\ 1 Unit of Parasitology and Parasitic Diseases, Department of Veterinary Medicine and Animal Production, \\ University of Naples Federico II, Via Delpino 1, 80137 Napoli, Italy; giuseppe.cringoli@unina.it (G.C.); \\ laura.rinaldi@unina.it (L.R.) \\ 2 Unit of Infectious Diseases of Domestic Animals, Department of Veterinary Medicine and Animal \\ Production, University of Naples Federico II, via Mezzocannone, 8-80134 Napoli, Italy; \\ alessandro.fioretti@unina.it (A.F.); luciafrancesca.menna@unina.it (L.F.M.) \\ * Correspondence: mariapaola.maurelli@unina.it (M.P.M.); antonio.santaniello2@unina.it (A.S.); \\ Tel.: +39-081-2536014 (M.P.M.); +39-081-2536134 (A.S.)
}

Received: 31 July 2019; Accepted: 15 October 2019; Published: 19 October 2019

Simple Summary: Animal-assisted interventions (AAIs) represent an opportunity for the well-being and health of people, but it is necessary that the animals involved in these interventions are subjected to very thorough health checks in order to avoid the potential risk of zoonoses transmission. Dogs are the main animal species involved in AAIs and may represent a potential reservoir of zoonotic agents (e.g., bacteria, parasites, fungi). Some scientific contributions have been published regarding healthcare checks and related hygiene measures for dogs involved in these interventions, but no attention has been paid to the presence of Toxocara eggs on the fur. Thus, a systematic review was carried out to address this topic. Although the infection of humans through the transmission of Toxocara eggs after direct contact with dogs must be critically challenged, we suggest including the examination of fur during a complete parasitological screening of dogs involved in AAIs in order to exclude hair coat contamination with zoonotic helminth eggs. Moreover, it is important to also monitor the behaviors of dogs that can increase the risk of contamination from the environment (e.g., roll on grass and feces of other dogs or cats) as well as the life habits of dogs (e.g., outdoor or indoor).

Abstract: Animal-assisted interventions (AAIs) usually contribute to the well-being and health of users/patients, but it is essential that the animals involved in these activities do not represent a source of zoonoses. This systematic review focused on the evaluation of the potential risk of the transmission of Toxocara by dogs' fur, considering their involvement as the main animal species in AAIs. Three databases were considered: MEDLINE/PubMed, Scopus, and Web of Science, and the PRISMA guidelines were used. Out of 162 articles found, 14 papers were identified as eligible for inclusion in the review. Although the findings were very heterogeneous, they showed that regular parasitological surveillance to plan effective control programs is strongly needed to guarantee the health of pets and consequently the public health, according to the concept of One Health. Since AAIs involve patients and/or users potentially susceptible, it is very important to appropriately treat dogs enrolled in these interventions after an accurate diagnosis of parasitic zoonoses.

Keywords: zoonosis; animal-assisted interventions; public health; fur; dog 


\section{Introduction}

Animals can contribute to many aspects of human wellbeing, health, and education through their involvement in animal-assisted interventions (AAIs) [1-5] that are defined as "Goal oriented and structured interventions that intentionally include or incorporate animals in health, education and human services (e.g., social work) for the purpose of therapeutic gains in humans" [6]. AAIs include human-animal teams in formal human services such as animal-assisted therapy (AAT), animal-assisted education (AAE), or animal-assisted activity (AAA). Commonly, AAIs are increasingly performed in support of healthcare within a wide range of physical and mental health problems in hospitals, rehabilitation clinics, psychiatric facilities, prisons, schools, nursing homes, etc. [7]. As reported by Shen et al. [8] and Glenk [9], various domestic animal species are involved in AAIs, but dogs are the most widely studied and most widely involved animal, especially in AAT.

In the context of AAIs, patients and/or users interact with dogs and such interaction can include several relational activities such as petting, physical contact, brushing, playing, and strolling with the dog. Particularly, it should be noted that "bodily contact" is one of the main features contributing to AAIs effectiveness, even in different settings [8]. In fact, during these activities, the patients (e.g., immunocompromised individuals, elderly, and children) and/or the users continuously come into contact with the dog (and also with its fur), thus being potentially exposed to zoonotic agents such as bacteria, fungi, and parasites [10-13] even when dogs are asymptomatic [14,15].

Toxocara canis is one of the most widespread zoonotic parasites in Europe [14]. Canids that are the definitive hosts of this parasite become infected, ingesting embryonated eggs from the environment or larvae in paratenic hosts (e.g., rodents) [16]. Puppies can also be infected vertically by transplacental or transmammary transmission from the bitch [14]. Infected definitive hosts excrete eggs of T. canis in the environment with feces and after a period of 2-6 weeks they become infective, depending on soil type and environmental conditions such as temperature and humidity. The eggs of T. canis are very resistant and can survive in the environment for months to years, under optimal circumstances [14].

Diagnosis of $T$. canis is traditionally performed using copromicroscopic techniques to detect eggs that can be differentiated from zoonotic $T$. cati eggs either through an accurate morphological examination [17] or by molecular analysis [18]. However, it should be noted that identification of Toxocara eggs to species level have seldom been reported in the scientific literature, and many papers that were published in the past used the term "T. canis" for eggs of Toxocara spp. without exact species determination. However, it is worth underlining that some authors $[17,19,20]$ showed the presence of T. cat i in dog feces with a percentage ranging from 7.3 to $34.5 \%$ of Toxocara eggs in the feces of dogs. The presence of $T$. cati could be mainly attributed to coprophagia of cat feces by dogs [20].

Both species (T. canis and T. cati) are of zoonotic importance, causing human toxocarosis. The main route of infection for humans is by oral ingestion of embryonated eggs of Toxocara spp. (e.g., by food and water contaminated or unwashed hands dirty with contaminated soil) [21]. Toxocara spp. infections in humans cause visceral, ocular, neuronal larva migrans, and occult toxocarosis [22]. Visceral larva migrans is sometimes asymptomatic, but the common clinical signs are coughing, asthma, bronchospasm, myalgia, abdominal pain, anorexia, occasionally myocarditis, or cutaneous manifestations (e.g., pruritus, rash, eczema, etc.). Ocular larva migrans causes decreased vision, ophthalmitis, chorioretinitis, and unilateral or bilateral blindness. Neuronal larva migrans causes meningitis, encephalitis, cerebral vasculitis, or myelitis. Finally, occult toxocarosis does not present specific symptoms [23,24].

Public parks, playgrounds, sandpits, etc. may become areas of Toxocara infection for humans and dogs [14]. Children mainly become infected in this way, because they are frequently in contact with contaminated soil/sand and could practice geophagia [25]. In Italy, environmental contamination of Toxocara spp. eggs was evaluated in different cities, with a prevalence of $33.6 \%$ in the Marche region, $7.0 \%$ in Milan, 3.6\% in Messina and Teramo, 2.5\% in Bari, $1.9 \%$ in Rome, $0.7 \%$ in Naples and in Padua, and $0.5 \%$ in Alghero, as reviewed by Traversa et al. [26]. 
The prevention of zoonotic risks represents one of the main objectives of the veterinary profession, therefore, the aim of this review was to focus our attention on the potential risk of Toxocara eggs transmission through contact with dogs' fur.

Considering that few data are available in the scientific literature regarding the health and welfare of animals involved in AAIs [27-29], our findings could be useful to promote parasite control plans for healthy dogs involved in the AAIs, encouraging the cooperation between human and veterinary medicine according to the concept of One Health [30-32].

\section{Materials and Methods}

\subsection{Systematic Review Protocol}

This review was performed according to the Preferred Reporting Items for Systematic Reviews and Meta-Analyses (PRISMA) [33]: (1) preparation of a database search to detect potentially related articles, (2) assessment of the relevancy of papers, (3) evaluation of quality, and (4) data extraction.

\subsection{Search Strategy and Data Sources}

Two researchers (A.S. and M.P.M.) independently performed the systematic search using the following strings: Toxocara canis AND "hair", Toxocara canis AND "fur", Toxocara canis AND "coat". We also accepted all the contributions documenting T. canis on dog's fur if the authors did not perform any exact species determination (i.e., T. canis or T. cati) by morphological or molecular analysis. For this reason, we chose to refer to the genus name "Toxocara" throughout the review.

Papers on the presence of eggs of Toxocara on dogs' fur were sorted by title and abstract and then screened to remove duplicates before the final selection. Original research English studies (published or in press) were included, while reviews, comments, letters, etc. without original data were excluded from this systematic review (Supplementary Materials, Table S1). Other related papers including references from selected papers were revised and used as supplementary information sources. In our study, the scientific literature published until 31 May 2019 on the topic of this review (see below) was included using three scientific electronic databases: MEDLINE/PubMed [34], Scopus [35], and Web of Science [36].

\subsection{Quality Assessment and Data Extraction}

The papers for full text review were considered eligible if they contained information related to the risks of zoonotic transmission of Toxocara eggs through the fur of dogs; whereas those focusing on the epidemiology of Toxocara spp. based on copromicroscopic surveys were excluded. No restrictions were applied based on age, breed, health status, and living conditions of dogs, nor regarding the technique used to detect the eggs of Toxocara. During the first screenings, duplicate or irrelevant papers were excluded.

The same investigators (A.S. and M.P.M.) separately assessed the papers considering the criteria enunciated above, according to the PRISMA protocol [33].

\section{Results}

The search returned a total of 162 documents. After removing the duplicates and irrelevant results, 49 articles were obtained for the complete revision of the entire text. Following the final evaluation, 14 sources were obtained for the systematic review (Figure 1). 

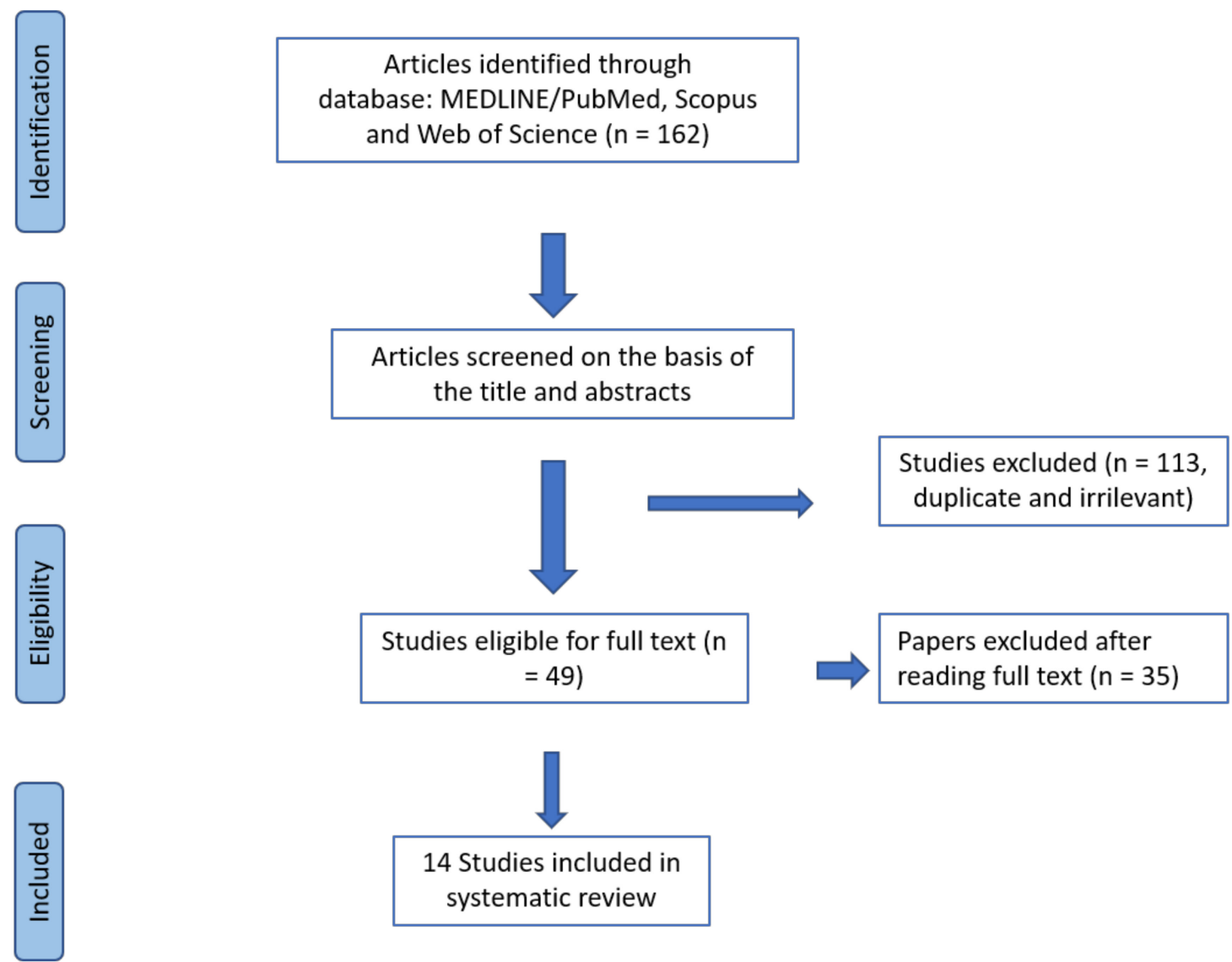

Figure 1. Flow diagram of the steps followed in the search strategy.

Study Selection and Characteristics

Table 1 reports the main findings for each of the 14 studies included in this systematic review.

The 14 studies were published between 2003 and 2018. Five papers (35.7\%) were performed in Europe [37-41], four $(28.6 \%)$ in Asia [22,42-44], two (14.3\%) in Africa [23,45], and three $(21.4 \%)$ in America [46-48].

The number of dogs enrolled in these studies ranged from 51 [22] to 267 [45] with different attitudes (owned, stray/kennelled, hunting, and sheep dogs), but most of them were owned dogs (in $11 / 14$ papers $=78.6 \%)$.

Seven papers focused on the sampling of dog fur and feces (50\%) [22,23,38,40,43-45], whilst six only on fur sampling $(42.9 \%)[39,41,42,46-48]$, finally one study was based on fur collection and the euthanasia of dogs (7.1\%) [37].

Fur samples were collected only from the perianal region in one study [46], whereas in the other papers, fur samples were collected on different body regions, from two (perianal and dorsum) [37,42] to seven (head, neck, ventral and lateral abdomen, perianal, hindquarters, and tail region) [44].

The percentage of dogs with Toxocara spp. eggs on fur ranged from a minimum of $2.9 \%$ [38] to a maximum of $67.0 \%$ [37], whilst dogs with positive fecal samples for Toxocara spp. ranged from $4.4 \%$ [40] to $76.2 \%$ [45]. In most studies, positive fecal samples were higher than the positive fur samples excluding Overgaauw et al. [40], who revealed $4.4 \%$ of positivity in feces and $12.2 \%$ on fur. Sowemimo and Ayanniyi [45] showed that dogs positive for fur were all positive for feces. Similar results were also reported by El-Tras et al. [23] for domestic dogs, whilst for stray dogs, two animals (3.8\%; CI 95\% $=0.7-14.1 \%$ ) showed positive hair samples, but negative fecal samples. Finally, Oge et al. [43] did not find dogs positive for fur and feces contemporaneously. 
Table 1. Characteristics of the studies concerning the presence of Toxocara eggs on the fur of dogs.

\begin{tabular}{|c|c|c|c|c|c|c|c|c|}
\hline $\begin{array}{c}\text { First Author, Year of } \\
\text { Publication }\end{array}$ & $\begin{array}{c}\text { Number of } \\
\text { Dogs }\end{array}$ & Type of Sample & Age of Dogs & $\begin{array}{l}\text { Fur Length/Breed } \\
\text { Involved }\end{array}$ & Attitude & $\begin{array}{l}\text { Prevalence of } \\
\text { Positive Fur } \\
\text { Dogs (\%) }\end{array}$ & $\begin{array}{c}\text { Body Region: } \\
\text { Prevalence per Fur Area } \\
\text { Sampled }\end{array}$ & Reference \\
\hline Sivajothi, 2018 & 236 & Fur and feces & $\begin{array}{c}<1 \text { year } \\
1-6 \text { years } \\
>6 \text { years }\end{array}$ & $\begin{array}{l}\text { Long hair coated dogs } \\
\text { Short hair coated dogs }\end{array}$ & N.A. & $60 / 236(25.4)$ & $\begin{array}{c}\text { Perianal region: } 86.67 \% \text {; } \\
\text { Tail regions: } 56.67 \% \text {; } \\
\text { Ventral and lateral } \\
\text { abdomen: } 51.67 \% \text {; } \\
\text { Head and Neck region: } \\
36.67 \%\end{array}$ & [44] \\
\hline Merigueti, 2017 & 165 & Fur & $\begin{array}{l}<1 \text { year } \\
>1 \text { year }\end{array}$ & $\begin{array}{l}\text { Short } \\
\text { Long }\end{array}$ & $\begin{array}{l}\text { Stray } \\
\text { Owned }\end{array}$ & $11 / 165(6.7)$ & $\begin{array}{c}\text { Perianal region: } 72.39 \% \\
\text { Upper tail regions: } \\
22.39 \%\end{array}$ & [47] \\
\hline Rojas, 2017 & 96 & Fur & $\begin{array}{l}\text { Young } \\
\text { Adult } \\
\text { Geriatric }\end{array}$ & $\begin{array}{l}\text { Short }(\leq 0.5 \mathrm{~cm}) \\
\text { Long }(>0.5 \mathrm{~cm})\end{array}$ & $\begin{array}{c}\text { Stray dog } \\
\text { Not stray dog }\end{array}$ & $40 / 96(41.7)$ & $\begin{array}{c}\text { Head: } 14.58 \% ; \\
\text { Perianal region: } 20.83 \% ; \\
\text { Hindquartes: } 10 / 10.82 \%\end{array}$ & [48] \\
\hline Sowemimo, 2016 & 267 & Fur and feces & $\begin{array}{l}0-6 \text { months } \\
7-12 \text { months } \\
>12 \text { months }\end{array}$ & $\begin{array}{l}\text { Local } \\
\text { Exotic }\end{array}$ & $\begin{array}{l}\text { Free-roaming } \\
\text { Kennel }\end{array}$ & $48 / 267(18.0)$ & $\begin{array}{c}\text { Neck: } 45.83 \% ; \\
\text { Back: } 47.91 \% ; \\
\text { Anal region: } 35.42 \%\end{array}$ & [45] \\
\hline Paoletti, 2015 & 676 & $\begin{array}{c}\text { Feces }(\mathrm{n}=502) \\
\text { and } \\
\text { Fur }(\mathrm{n}=174)\end{array}$ & $\begin{array}{l}\leq 12 \text { months } \\
>12 \text { months }\end{array}$ & N.A. & $\begin{array}{l}\text { Private dogs } \\
\text { Kenneled dogs }\end{array}$ & $5 / 174(2.9)$ & N.A. & [38] \\
\hline Oge, 2014 & 100 & Fur and feces & $\begin{array}{c}\text { Puppy (<6 months) } \\
\text { Young } \\
(6-12 \text { months }) \\
\text { Adult (>12 months) }\end{array}$ & N.A. & Owned dogs & $14 / 100(14.0)$ & N.A. & [43] \\
\hline Tavassoli, 2012 & 138 & Fur & $\begin{array}{l}\text { Puppy (<6 months) } \\
\text { Adult ( }>6 \text { months) }\end{array}$ & Different breeds & $\begin{array}{c}\text { Farm sheepdogs } \\
\text { Pet Dogs }\end{array}$ & $50 / 138(36.2)$ & N.A. & [42] \\
\hline
\end{tabular}


Table 1. Cont.

\begin{tabular}{|c|c|c|c|c|c|c|c|c|}
\hline $\begin{array}{l}\text { First Author, Year of } \\
\text { Publication }\end{array}$ & $\begin{array}{l}\text { Number of } \\
\text { Dogs }\end{array}$ & Type of Sample & Age of Dogs & $\begin{array}{l}\text { Fur Length/Breed } \\
\text { Involved }\end{array}$ & Attitude & $\begin{array}{l}\text { Prevalence of } \\
\text { Positive Fur } \\
\text { Dogs (\%) }\end{array}$ & $\begin{array}{c}\text { Body Region: } \\
\text { Prevalence per Fur Area } \\
\text { Sampled }\end{array}$ & Reference \\
\hline El-Tras, 2011 & 120 & $\begin{array}{l}\text { Fur and feces } \\
\quad(\mathrm{n}=100) \\
\text { Fur }(\mathrm{n}=20)\end{array}$ & $\begin{array}{l}\text { Puppy < } 6 \text { months }) \\
\text { Young }(6-12 \text { months }) \\
\text { Adult ( }>1 \text { year })\end{array}$ & $\begin{array}{l}\text { Breed and fur type } \\
\text { according to } \\
\text { Sato et al. [49] }\end{array}$ & $\begin{array}{c}\text { Stray dogs } \\
\text { Domestic dogs }\end{array}$ & $\begin{array}{l}\text { 17/64 (26.6 stray) } \\
\text { and 6/56 (10.7 } \\
\text { domestic) }\end{array}$ & N.A. & [23] \\
\hline Keegan, 2010 & 182 & Fur & $\begin{array}{l}<1 \text { year } \\
>1 \text { year }\end{array}$ & $\begin{array}{l}\text { Short } \\
\text { Long }\end{array}$ & $\begin{array}{l}\text { Dog grooming } \\
\text { parlor } \\
\text { Veterinary } \\
\text { practiceIndividual } \\
\text { dog owner } \\
\text { Boarding kennel }\end{array}$ & $16 / 182(8.8)$ & $\begin{array}{c}\text { Head: } 31.25 \% \\
\text { Neck: } 25.0 \% \\
\text { Back: } 43.75 \% \\
\text { Perianal region: } 18.75 \%\end{array}$ & [41] \\
\hline Amaral, 2010 & 104 & Fur & $\begin{array}{l}\text { Puppy ( }<6 \text { months }) \\
\text { Juvenile } \\
\text { (6-12 months) } \\
\text { Adult ( }>12 \text { months })\end{array}$ & $\begin{array}{l}\text { Short } \\
\text { Long }\end{array}$ & $\begin{array}{l}\text { Stray dogs } \\
\text { Owned dogs }\end{array}$ & 25/104 (24.0) & Perianal region: $24.0 \%$ & [46] \\
\hline Overgaauw, 2009 & 240 & $\begin{array}{c}\text { Fur }(n=148) \\
\text { and } \\
\text { feces }(n=92)\end{array}$ & $0.5-13$ years & $\begin{array}{l}\text { Short hair breed } \\
\text { Long hair breed }\end{array}$ & N.A. & $18 / 148(12.2)$ & N.A. & [40] \\
\hline Roddie, 2008 & 100 & Fur and feces & $\begin{array}{l}\text { Puppy ( }<6 \text { months }) \\
\text { Juvenile } \\
\text { (6-12 months) } \\
\text { Adult ( }>12 \text { months })\end{array}$ & N.A. & Stray dogs & $67 / 100(67.0)$ & N.A. & [37] \\
\hline $\begin{array}{l}\text { Aydenizoz-Ozkayhan, } \\
2008\end{array}$ & 51 & Fur & $\begin{array}{l}\text { Puppy } \\
\text { Young } \\
\text { Adult }\end{array}$ & $\begin{array}{l}\text { Short } \\
\text { Medium } \\
\text { Long }\end{array}$ & Breeds * & $11 / 51(21.57)$ & N.A. & [22] \\
\hline Wolfe, 2003 & 60 & Fur & 8 weeks -15 years & N.A. & $\begin{array}{c}\text { Animal care } \\
\text { shelters } \\
\text { Working farm } \\
\text { dogs } \\
\text { Domestic Pets }\end{array}$ & $15 / 60(25.0)$ & N.A. & [39] \\
\hline
\end{tabular}

N.A.: Not available; * Size, hair length, and coat type of the dogs were classified according to the American Kennel Club (AKC) [50] and The Kennel Club [51]. 
Moreover, different risk factors (age, gender, hair length/breed, coat type, body weight, attitude of dogs, soil contact) that could influence the presence of Toxocara eggs on fur were evaluated in the papers analyzed. Age of the enrolled dogs ranged from 34 days [22] to 15 years [39]. In three papers [39-41], higher prevalence was found in adults ( $>12$ months) than in young dogs ( 6 months -1 year) and puppies $(<6$ months $)(p<0.05)$. In contrast, other authors reported a higher prevalence of positivity for Toxocara spp. on fur in puppies [22,23,37,38,42,46,47]. No significant association with age was found by Oge et al. [43], Sivajothi and Reddy [44], Sowemimo and Ayanniyi [45], and Rojas et al. [48].

Regarding gender, some papers have shown higher positivities (presence of Toxocara eggs on $\mathrm{dog}^{\prime}$ 's fur) either in female $[23,46,47]$ or in male $[22,42,45,48]$ dogs; however, these authors did not report any significant difference based on gender.

No associations were found with other risk factors as body weight, coat type, and soil contact $(p>0.05)$. Only Merigueti et al. [47] found an association between positivity and half-breed dogs $(p=0.0099)$, whilst Sowemimo and Ayanniyi [45] showed that there were significant differences of positivity between local (African shepherd) and exotic breeds $(p<0.05)$.

The number of Toxocara eggs collected from fur ranged from 26 [41] to 39,120 [37]. Only some authors identified the species (i.e., T. canis) of eggs recovered from fur by morphological or molecular analysis $[22,23,39,42,45,46]$.

Viability of eggs recovered from fur was evaluated in 11/14 (78.6\%) papers according to their morphological characteristics: non-viable eggs (not intact), viable/unembryonated (intact egg with content), embryonating (egg with two or more cell divisions), and embryonated (containing larvae) [22,37]. Viable eggs were found by Wolfe and Wright [39], Aydenizöz-Özkayhan et al. [22], Roddie et al. [37], Amaral et al. [46], and Merigueti et al. [47] with a prevalence of $50.7 \%, 79.0 \%$, $70.8 \%, 53.0 \%$, and $86.6 \%$, respectively. Embryonating eggs, instead, were found by Wolfe and Wright [39], Aydenizöz-Özkayhan et al. [22], Roddie et al. [37], Amaral et al. [46], and Merigueti et al. [47] with a prevalence of $23.9 \%, 12.9 \%, 70.8 \%, 2.0 \%$, and $13.4 \%$, respectively. Keegan and Holland [41] and Oge et al. [43] found only one embryonating egg with a prevalence of $0.7 \%$ and $3.8 \%$, respectively. Moreover, embryonated eggs were found by Wolfe and Wright [39], Roddie et al. [37], Aydenizöz-Özkayhan et al. [22], El-Tras et al. [23] with prevalence of $4.2 \%, 0.3 \%, 8.1 \%$ and $2.4 \%$, respectively. Finally, Overgaauw et al. [40], Sowemimo and Ayanniyi [45], and Paoletti et al. [38] found unembryonated eggs in all fur samples analyzed.

Different authors have also evaluated the fur length and its correlation with egg viability $[22,38,40,41,46,47]$. Amaral et al. [46] found about $86 \%$ of the viable eggs on short hair dogs, with a difference statistically significant when compared to long hair dogs $(p<0.0001)$. Similarly, Roddie et al. [37] found a higher prevalence of embryonation rate in puppies than in adult dogs.

\section{Discussion}

The scientific literature used in this systematic review highlighted the possibility of the transmission of Toxocara spp. to people and other dogs through contact with the fur of dogs contaminated by eggs.

Overgaauw and von Knapen [52], Overgaauw et al. [40], Keegan and Holland [41], and Nagy et al. [19] suggested that there was a low risk of infection with eggs of Toxocara spp. on fur due to the low prevalence of embryonated eggs $(0-4 \%)$ found in their studies. Moreover, Overgaauw et al. [40] also showed that in the case of highly contaminated fur with embryonated eggs (i.e., 12 eggs per gram, by Wolfe and Wright [39]), more than $4 \mathrm{~g}$ of hair sample was necessary to ingest 50 infective eggs.

However, Aydenizöz-Özkayhan et al. [22] found a higher number of eggs per gram of Toxocara on fur than in soil: 18.05 eggs per gram of hair vs. 0.09 per $30 \mathrm{~g}$ and 0.067 per $100 \mathrm{~g}$ of soil. Moreover, Oge et al. [43] showed that dog feces were negative for Toxocara spp., whilst the dogs' fur samples were positive, representing a silent potential risk for humans. Therefore, although soil contamination is the main cause of most cases of larva migrans in humans, the transmission of Toxocara eggs by direct contact with dogs should not be underestimated. 
The findings of the analyzed papers highlighted that the source of eggs on fur could be different for stray dogs as well as for adult dogs; in fact, they could acquire Toxocara through contact with contaminated environments whilst for owned dogs and puppies, it could be due to self-contamination as reported by Roddie et al. [37], El-Tras et al. [23], and Sowemimo and Ayanninyi [45]. This hypothesis was also confirmed by Roddie et al. [37], who found a positive correlation between the number of worms collected after euthanasia and the number of Toxocara eggs on the puppies' fur, therefore adult dogs could become contaminated by scent-rolling.

Merigueti et al. [47] found a prevalence significantly higher in stray than in owned dogs due to a lack of anthelmintic treatments. El-Tras et al. [23], instead reported that stray habits were not significant risk factors, but fur from stray dogs presented a higher number of eggs per gram than fur from owned dogs.

A different viability of eggs was found in different studies. This high difference may be attributed to variations between environmental conditions (e.g., temperature and humidity). Although a low prevalence of embryonated infective eggs was found in the studies analyzed [22,23,37,39], unembryonated Toxocara eggs can develop fully on the fur under controlled conditions, as reported by Keegan and Holland [53]. In contrast, Nagy et al. [19] showed that Toxocara eggs on dogs' fur did not develop to embryonated eggs, but the same authors did not exclude the contamination of the dogs' fur with embryonated eggs from the environment.

In two studies [37,46], a significant correlation between the viability of Toxocara eggs on fur and breed/coat type was found; in both studies, authors reported that in dogs with short hair (as well as in puppies) there was a greater closeness of Toxocara eggs with the skin, where the temperature conditions are suitable for the development of the eggs.

In all of the studies, the perianal area, the back and tail resulted in sites where a higher number of Toxocara eggs were collected from the dog's fur $[23,37,43,44,47,48]$, whilst in Sowemimo and Ayanniyi [45], the neck region showed higher egg numbers. However, Toxocara eggs were also found in other regions such as the head, abdomen, and limbs [23,41,44-46], thus showing a potential zoonotic risk for humans because these sites represent areas of contact with people and other dogs. This risk could be potentially higher in AAIs, involving patients and/or users more susceptible (young or old and immunosuppressed people) to zoonotic infections $[10,11,54,55]$. Moreover, during AAIs, bodily contact (i.e., petting, embrace, staying close) is very important, as reported by Shen et al. [8] because it is considered a desirable behavior for patients/users, and a fundamental element for the effectiveness of the interventions themselves.

The age of dogs could not be a key risk factor, in fact, some authors showed a higher prevalence in dogs $>12$ months [39-41], whilst others in puppies, justifying the higher prevalence of Toxocara eggs found on the fur with correlation to the higher number of sources of infections in puppies than in older dogs $[22,23,37,38,42,46,47]$. Recent studies on the characteristics of dogs involved in the AAIs underline the need to consider subjects of at least one year of age that are able to express an intraspecific and interspecific assortment of behaviors, useful for the interaction with patients/users [6,27,28,56-58].

Although the number of studies included in this systematic review was low (only 14 papers) and their experimental designs were very heterogeneous (e.g., number of dogs involved, age, breed, length of fur, etc.), these findings may contribute to increase attention to the potential zoonotic risks related to dogs included in AAIs. However, the current scientific literature concerning potential zoonotic risks during AAIs [28,54] never refers to the hazard deriving from the presence of Toxocara or other helminth eggs on dogs' fur. Therefore, a regular and complete parasitological monitoring of dogs involved in AAIs is advisable in order to prevent animal and/or human infection [59].

\section{Conclusions}

Even if the studies considered in this systematic review evidenced a low prevalence of infectious (embryonated) eggs of Toxocara spp. on dog's fur, the potential zoonotic risk should not be disregarded. In addition, it is important to underline that dog hair may be contaminated with eggs of other helminths 
(e.g., the Taeniidae Echinococcus multilocularis and Echinococcus granulosus sensu lato) that may have a higher potential of zoonotic infection, because eggs of these species are immediately infective [19,60].

Therefore, the following veterinary actions would be advisable for dogs involved in AAIs: (1) to improve the health care surveillance through an accurate and regular parasitological monitoring not only of feces but also of dogs' fur; (2) to monitor the activities and lifestyle of dogs (food, habitat, interaction with other dogs or other animals, attendance of dog areas in the park, rolling on grass or feces or animal carcasses) in the days and/or in the steps preceding the sessions with patient and/or user involved in AAIs; and (3) to improve hygiene procedures before and after handling and/or contact with dogs.

Supplementary Materials: The following are available online at http://www.mdpi.com/2076-2615/9/10/827/s1, Table S1: Papers Excluded from Systematic Review.

Author Contributions: Conceptualization, A.S.; Methodology, A.S. and M.P.M.; Investigation, A.S. and M.P.M.; Writing-original draft preparation, A.S. and M.P.M.; Writing—review and editing, G.C., A.F., L.R., and L.F.M.; Supervision, L.R. and L.F.M.

Funding: This research received no external funding.

Conflicts of Interest: The authors declare no conflicts of interest.

\section{References}

1. Menna, L.F.; Santaniello, A.; Gerardi, F.; Di Maggio, A.; Milan, G. Evaluation of the efficacy of animal-assisted therapy based on the reality orientation therapy protocol in Alzheimer's disease patients: A pilot study. Psychogeriatrics 2016, 16, 240-246. [CrossRef]

2. Dicé, F.; Santaniello, A.; Gerardi, F.; Menna, L.F.; Freda, M.F. Meeting the Emotion! Application of the Federician Model for Pet Therapy to an experience of Animal Assisted Education (AAE) in a primary school. Prat. Psychol. J. 2017, 23, 455-463. [CrossRef]

3. Menna, L.F.; Santaniello, A.; Gerardi, F.; Sansone, M.; Di Maggio, A.; Di Palma, A.; Perruolo, G.; D’Esposito, V.; Formisano, P. Efficacy of animal-assisted therapy adapted to reality orientation therapy: Measurement of salivary cortisol. Psychogeriatrics 2019. [CrossRef]

4. Jones, M.G.; Rice, S.M.; Cotton, S.M. Incorporating animal-assisted therapy in mental health treatments for adolescents: A systematic review of canine assisted psychotherapy. PLoS ONE 2019, 14, e0210761. [CrossRef]

5. Wijker, C.; Leontjevas, R.; Spek, A.; Enders-Slegers, M.J. Effects of Dog Assisted Therapy for Adults with Autism Spectrum Disorder: An Exploratory Randomized Controlled Trial. J. Autism Dev. Disord. 2019. [CrossRef] [PubMed]

6. IAHAIO. IAHAIO White Paper 2014, Updated for 2018. The IAHAIO Definitions for Animal Assisted Intervention and Guidelines for Wellness of Animals Involved in AAI. 2018. Available online: http://iahaio. org/wp/wpcontent/uploads/2018/04/iahaio_wp_updated-2018-final.pdf (accessed on 10 December 2018).

7. Hediger, K.; Meisser, A.; Zinsstag, J. A One Health Research Framework for Animal-Assisted Interventions. Int. J. Environ. Res. Public Health 2019, 16, 640. [CrossRef] [PubMed]

8. Shen, R.Z.Z.; Xionga, P.; Choua, U.I.; Hall, B.J. "We need them as much as they need us": A systematic review of the qualitative evidence for possible mechanisms of effectiveness of animal-assisted intervention (AAI). Complement. Ther. Med. 2018, 41, 203-207. [CrossRef] [PubMed]

9. Glenk, L.M. Current Perspectives on Therapy Dog Welfare in Animal-Assisted Interventions. Animals 2017, 7, 7. [CrossRef] [PubMed]

10. Brodie, S.J.; Biley, F.C.; Shewring, M. An exploration of the potential risks associated with using pet therapy in healthcare settings. J. Clin. Nurs. 2002, 11, 444-456. [CrossRef] [PubMed]

11. Mani, I.; Maguire, J.H. Small animal zoonoses and immuncompromised pet owners. Top. Companion Anim. Med. 2009, 24, 164-174. [CrossRef]

12. Ghasemzadeh, I.; Namazi, S.H. Review of bacterial and viral zoonotic infections transmitted by dogs. J. Med. Life 2015, 8, 1-5. [PubMed]

13. Gerardi, F.; Santaniello, A.; Del Prete, L.; Maurelli, M.P.; Menna, L.F.; Rinaldi, L. Parasitic infections in dogs involved in animal-assisted interventions. Ital. J. Anim. Sci. 2018, 1, 269-272. [CrossRef] 
14. Baneth, G.; Thamsborg, S.M.; Otranto, D.; Guillot, J.; Blaga, R.; Deplazes, P.; Solano-Gallego, L. Major Parasitic Zoonoses associated with Dogs and Cats in Europe. J. Comp. Pathol. 2016, 155, S54-S74. [CrossRef] [PubMed]

15. Boyle, S.F.; Corrigan, V.K.; Buechner-Maxwell, V.; Pierce, B.J. Evaluation of Risk of Zoonotic Pathogen Transmission in a University-Based Animal Assisted Intervention (AAI) Program. Front. Vet. Sci. 2019, 6, 167. [CrossRef] [PubMed]

16. Dubinský, P.; Havasiová-Reiterová, K.; Petko, B.; Hovorka, I.; Tomasovicová, O. Role of small mammals in the epidemiology of toxocariasis. Parasitology 1995, 110, 187-193. [CrossRef] [PubMed]

17. Fahrion, A.S.; Schnyder, M.; Wichert, B.; Deplazes, P. Toxocara eggs shed by dogs and cats and their molecular and morphometric species-specific identification: Is the finding of T. cati eggs shed by dogs of epidemiological relevance? Vet. Parasitol. 2011, 177, 186-189. [CrossRef]

18. Jacobs, D.E.; Zhu, X.; Gasser, R.B.; Chilton, N.B. PCR-based methods for identification of potentially zoonotic ascaridoid parasites of the dog, fox and cat. Acta Trop. 1997, 68, 191-200. [CrossRef]

19. Nagy, A.; Ziadinov, I.; Schweiger, A.; Schnyder, M.; Deplazes, P. Hair coat contamination with zoonotic helminth eggs of farm and pet dogs and foxes. Berl. Munch. Tierarztl. Wochenschr. 2011, 124, 503-511.

20. Vienažindienè, Ž.; Joekel, D.E.; Schaper, R.; Deplazes, P.; Šarkūnas, M. Longitudinal study for anthelmintic efficacy against intestinal helminths in naturally exposed Lithuanian village dogs: Critical analysis of feasibility and limitations. Parasitol. Res. 2018, 117, 1581-1590. [CrossRef]

21. Deplazes, P.; Van Knapen, F.; Schweiger, A.; Overgaauw, P.A.M. Role of pet dogs and cats in the transmission of helminthic zoonoses in Europe, with a focus on echinococcosis and toxocarosis. Vet. Parasitol. 2011, 182, 41-53. [CrossRef]

22. Aydenizöz-Ozkayhan, M.; Yağci, B.B.; Erat, S. The investigation of Toxocara canis eggs in coats of different dog breeds as a potential transmission route in human toxocariasis. Vet. Parasitol. 2008, 152, 94-100. [CrossRef] [PubMed]

23. El-Tras, W.F.; Holt, H.R.; Tayel, A.A. Risk of Toxocara canis eggs in stray and domestic dog hair in Egypt. Vet. Parasitol. 2011, 178, 319-323. [CrossRef] [PubMed]

24. Rostami, A.; Ma, G.; Wang, T.; Koehler, A.V.; Hofmann, A.; Chang, B.C.H.; Macpherson, C.N.; Gasser, R.B. Human toxocariasis-A look at a neglected disease through an epidemiological 'prism'. Infect. Genet. Evol. 2019, 74, 104002. [CrossRef] [PubMed]

25. Youssef, A.I.; Uga, S. Review of the parasitic zoonoses in Egypt. Trop. Med. Health 2014, 42, 3-14. [CrossRef] [PubMed]

26. Traversa, D.; Frangipane di Regalbono, A.; Di Cesare, A.; La Torre, F.; Drake, J.; Pietrobelli, M. Environmental contamination by canine geohelminths. Parasit. Vectors 2014, 7, 67. [CrossRef]

27. Murthy, R.; Bearman, G.; Brown, S.; Bryant, K.; Chinn, R.; Hewlett, R.; George, G.; Goldstein, E.; Holzmann-Pazgal, G.; Rupp, M.; et al. Animals in Healthcare Facilities: Recommendations to Minimize Potential Risks. Infect. Control Hosp. Epidemiol. 2015, 36, 495-516. [CrossRef]

28. Hardin, P.; Brown, J.; Wright, M.E. Prevention of transmitted infections in a pet therapy program: An exemplar. Am. J. Infect. Control 2016, 44, 846-850. [CrossRef]

29. Linder, D.E.; Siebens, H.C.; Mueller, M.K.; Gibbs, D.M.; Freeman, L.M. Animal-assisted interventions: A national survey of health and safety policies in hospitals, eldercare facilities, and therapy animal organizations. Am. J. Infect. Control 2017, 45, 883-887. [CrossRef]

30. Zinsstag, J.; Schelling, E.; Waltner-Toews, D.; Tanner, M. From “one medicine" to "one health" and systemic approaches to health and well-being. Prev. Vet. Med. 2011, 101, 148-156. [CrossRef]

31. Chalmers, D.; Dell, C.A. Applying One Health to the Study of Animal-Assisted Interventions. Ecohealth 2015, 12, 560-562. [CrossRef]

32. Schurer, J.M.; Mosites, E.; Li, C.; Meschke, S.; Rabinowitz, P. Community-based surveillance of zoonotic parasites in a 'One Health' world: A systematic review. One Health 2016, 2, 166-174. [CrossRef] [PubMed]

33. Moher, D.; Liberati, A.; Tetzlaff, J.; Altman, D.G. PRISMA Group: Preferred reporting items for systematic reviews and meta-analyses: The PRISMA statement. Int. J. Surg. 2010, 8, 336-341. [CrossRef] [PubMed]

34. MEDLINE/PubMed. Available online: https://www.ncbi.nlm.nih.gov/pubmed (accessed on 31 May 2019).

35. Scopus. Available online: https://www.scopus.com/ (accessed on 31 May 2019).

36. Web of Science. Available online: https://clarivate.com/products/web-of-science/ (accessed on 31 May 2019).

37. Roddie, G.; Stafford, P.; Holland, C.; Wolfe, A. Contamination of dog hair with eggs of Toxocara canis. Vet. Parasitol. 2008, 152, 85-93. [CrossRef] [PubMed] 
38. Paoletti, B.; Traversa, D.; Iorio, R.; De Berardinis, A.; Bartolini, R.; Salini, R.; Di Cesare, A. Zoonotic parasites in feces and fur of stray and private dogs from Italy. Parasitol. Res. 2015, 114, 2135-2141. [CrossRef] [PubMed]

39. Wolfe, A.; Wright, I.P. Human toxocariasis and direct contact with dogs. Vet. Rec. 2003, 152, 419-422. [CrossRef]

40. Overgaauw, P.A.; Van Zutphen, L.; Hoek, D.; Yaya, F.O.; Roelfsema, J.; Pinelli, E.; Van Knapen, F.; Kortbeek, L.M. Zoonotic parasites in fecal samples and fur from dogs and cats in The Netherlands. Vet. Parasitol. 2009, 163, 115-122. [CrossRef]

41. Keegan, J.D.; Holland, C.V. Contamination of the hair of owned dogs with the eggs of Toxocara spp. Vet. Parasitol. 2010, 173, 161-164. [CrossRef]

42. Tavassoli, M.; Javadi, S.; Firozi, R.; Rezaei, F.; Khezri, A.; Hadian, M. Hair Contamination of Sheepdog and Pet Dogs with Toxocara canis Eggs. Iran. J. Parasitol. 2012, 7, 110-115.

43. Öge, H.; Öge, S.; Özbakış, G.; Gürcan, S. Comparison of Toxocara eggs in hair and faecal samples from owned dogs and cats collected in Ankara, Turkey. Vet. Parasitol. 2014, 206, 227-231. [CrossRef]

44. Sivajothi, S.; Reddy, B.S. Investigation on Toxocara spp. eggs in hair coat of dogs in YSR Kadapa district of Andhra Pradesh, India. J. Parasit. Dis. 2018, 42, 550-553. [CrossRef]

45. Sowemimo, O.A.; Ayanniyi, O.O. Presence of Toxocara Eggs on the Hairs of Dogs from Southwest Nigeria. J. Bacteriol. Parasitol. 2016, 7. [CrossRef]

46. Amaral,H.L.D.C.; Rassier, G.L.; Pepe, M.S.; Gallina, T.; Villela, M.M.; Nobre, M.D.O.; Scaini, C.J.; Berne, M.E.A. Presence of Toxocara canis eggs on the hair of dogs: A risk factor for Visceral Larva Migrans. Vet. Parasitol. 2010, 174, 115-118. [CrossRef] [PubMed]

47. Merigueti, Y.F.F.B.; Santarém, V.A.; Ramires, L.M.; Da Silveira Batista, A.; Da Costa Beserra, L.V.; Nuci, A.L.; De Paula Esposte, T.M. Protective and risk factors associated with the presence of Toxocara spp. eggs in dog hair. Vet. Parasitol. 2017, 244, 39-43. [CrossRef] [PubMed]

48. Rojas, T.O.; Romero, C.; Heredia, R.; Bautista, L.G.; Sheinberg, G. Identification of Toxocara spp. eggs in dog hair and associated risk factors. Vet. World 2017, 10, 798-802. [CrossRef] [PubMed]

49. Sato, H.; Matsuda, H.; Kubota, S.; Kawano, K. Statistical comparison of dog and cat guard hairs using numerical morphology. Forensic Sci. Int. 2006, 158, 94-103. [CrossRef] [PubMed]

50. American Kennel Club. Available online: www.akc.org (accessed on 12 September 2019).

51. The Kennel Club. Available online: www.thekennelclub.org.uk (accessed on 12 September 2019).

52. Overgaauw, P.A.; Van Knapen, F. Negligible risk of visceral or ocular larva migrans from petting a dog. Ned. Tijdschr. Geneeskd. 2004, 148, 1600-1603. [PubMed]

53. Keegan, J.D.; Holland, C.V. A comparison of Toxocara canis embryonation under controlled conditions in soil and hair. J. Helminthol. 2013, 87, 78-84. [CrossRef]

54. Bert, F.; Gualano, M.R.; Camussi, E.; Pieve, G.; Voglino, G.; Siliquini, R. Animal assisted intervention: A systematic review of benefits and risks. Eur. J. Integr. Med. 2016, 8, 695-706. [CrossRef]

55. Elad, D. Immunocompromised patients and their pets: Still best friends? Vet. J. 2013, 197, 662-669. [CrossRef]

56. Menna, L.F.; Santaniello, A.; Amato, A.; Ceparano, G.; Di Maggio, A.; Sansone, M.; Formisano, P.; Cimmino, I.; Perruolo, G.; Fioretti, A. Changes of Oxytocin and Serotonin Values in Dialysis Patients after Animal Assisted Activities (AAAs) with a Dog-A Preliminary Study. Animals 2019, 9, 526. [CrossRef]

57. Pet Partners. Available online: https://petpartners.org/learn/ (accessed on 9 September 2019).

58. Menna, L.F. The scientific approach to Pet therapy. In The Method and Training According to the Federiciano Model, 1st ed.; University of Naples Federico II: Napoli, Italy, 2018; ISBN 979-12-200-3991-8.

59. European Scientific Counsel Companion Animal Parasites. Available online: https://www.esccap.org/ (accessed on 12 September 2019).

60. Alvarez-Rojas, C.A.; Mathis, A.; Deplazes, P. Assessing the contamination of food and the environment with Taenia and Echinococcus eggs and their zoonotic transmission. Curr. Clin. Microbiol. Rep. 2018, 5, 154-163. [CrossRef]

(C) 2019 by the authors. Licensee MDPI, Basel, Switzerland. This article is an open access article distributed under the terms and conditions of the Creative Commons Attribution (CC BY) license (http://creativecommons.org/licenses/by/4.0/). 